\title{
MICROBIOLOGICAL QUALITY OF SOFT, SEMI-HARD AND HARD CHEESES DURING THE SHELF-LIFE
}

\author{
Josip Vrdoljak $^{1}$, Vesna Dobranić ${ }^{2}$, Ivana Filipović ${ }^{2}$ Nevijo Zdolec ${ }^{2}$ \\ ${ }^{1}$ PUĐA D.O.O., Economic Zone Čaporice 133, 21240 Čaporice, Croatia \\ ${ }^{2}$ Department of Hygiene, Technology and Food Safety, \\ Faculty of Veterinary Medicine, University of Zagreb, \\ Heinzelova 55, 10000 Zagreb, Croatia
}

Received 1 July 2015; Received in revised form 3 November 2015; Accepted 19 November 2015

\begin{abstract}
Cheeses as ready-to-eat food should be considered as a potential source of foodborne pathogens, primarily Listeria monocytogenes. The aim of present study was to determine the microbiological quality of soft, semi-hard and hard cheeses during the shelf-life, with particular reference to L. monocytogenes. Five types of cheeses were sampled at different timepoints during the cold storage and analyzed for presence of Salmonella and L. monocytogenes, as well as lactic acid bacteria, Escherichia coli, coagulase-positive staphylococci, yeasts, molds, sulfite-reducing clostridia and L. monocytogenes counts. Water activity, $\mathrm{pH}$ and $\mathrm{NaCl}$ content were monitored in order to evaluate the possibility of $L$. monocytogenes growth. Challenge test for L. monocytogenes was performed in soft whey cheese, to determine the growth potential of pathogen during the shelf-life of product. All analyzed cheeses were compliant with microbiological criteria during the shelf-life. In soft cheeses, lactic acid bacteria increased in the course of the shelf-life period (1.2-2.6 log increase), while in semi-hard and hard cheeses it decreased (1.6 and $5.2 \mathrm{log}$ decrease, respectively). Soft cheeses support the growth of L. monocytogenes according to determined $\mathrm{pH}$ values (5.8-6.5), water activity (0.99-0.94), and $\mathrm{NaCl}$ content $(0.3-1.2 \%)$. Challenge test showed that $L$. monocytogenes growth potential in selected soft cheese was $0.43 \log _{10} \mathrm{cfu} / \mathrm{g}$ during 8 days at $4^{\circ} \mathrm{C}$. Water activity in semi-hard and hard cheeses was a limiting factor for Listeria growth during the shelf-life. Soft, semi-hard and hard cheeses were microbiologically stable during their defined shelf-life. Good manufacturing and hygienic practices must be strictly followed in the production of soft cheeses as Listeria-supporting food and be focused on preventing (re)contamination.
\end{abstract}

Key words: cheese, shelf-life, L. monocytogenes

\section{INTRODUCTION}

Microbiological stability and safety of food during storage is related to many factors. Ready-to-eat food products, including cheeses, are intended for consumption without any treatment between final production step and consumption. The course of microbiological changes in different cheeses during storage and shelf-life depends on the production technology and cheese type (pasteurization, starters, acidity, ripening, etc.), physico-chemical properties

Corresponding author: Assist. Prof. Nevijo Zdolec, $\mathrm{PhD}$ E-mail address: nzdolec@vef hr

Present address: Department of Hygiene, Technology and Food Safety, Faculty of Veterinary Medicine, University of Zagreb,

Heinzelova 55, 10000 Zagreb, Croatia

Phone: ++38512390192

Copyright: (C) 2015 Vrdoljak J. This is an open-access article published under the terms of the Creative Commons Attribution License which permits unrestricted use, distribution, and reproduction in any medium, provided the original author and source are credited.

Competing Interests: The authors have declared that no competing interests exist.

Available Online First: 4 December 2015

Published on: 15 March 2016

http://dx.doi.org/10.1515/macvetrev-2015-0068 (acidity, moisture content, salt content), storage conditions (microclimate, handling, packaging). Listeria monocytogenes is the most important foodborne pathogen in cheese microbiology, mainly in the post-processing phase (5). European Regulation on microbiological criteria of food (EC 2073/2005) categorizes foods into two groups, supporting or not supporting the growth of L. monocytogenes. Foods with $\mathrm{pH} \leq 4.4$ or water activity $\left(\mathrm{a}_{\mathrm{w}}\right) \leq 0.92$, or products with $\mathrm{pH} \leq 5.0$ and $\mathrm{a}_{\mathrm{w}} \leq 0.94$, as well as products with shelf-life less than 5 days are considered as safe regarding Listeria outgrowth (4). Recent survey conducted by EFSA showed that $0.06 \%$ of soft and semisoft cheeses $(n=3452)$ are exceeding the level of $100 \mathrm{cfu} / \mathrm{g}$ at the end of shelf-life. The occurrence of L. monocytogenes in cheese samples was $0.47 \%$ (6). In Croatia, microbiological surveys in recent years were mainly performed on traditional dairy products from non-pasteurized milk, and L. monocytogenes was frequently present $(7,12)$. Thus, the aim of the 
present study was to evaluate the microbiological quality of pasteurized-milk cheeses during the shelflife with particular reference to L. monocytogenes prevalence and counts. The growth potential of $L$. monocytogenes was also evaluated in soft whey cheese during the shelf-life.

\section{MATERIAL AND METHODS}

Soft, semi-hard and hard cheeses were produced according to standard procedure in a local cheese producing plant and sampled at the end of production. Ten units of each cheese were sampled, stored in laboratory at $4^{\circ} \mathrm{C}$ and periodically analyzed during defined shelf-life (Table 1).
$\mathrm{pH}$ with $\mathrm{pH}-$ meter $(\mathrm{pH} 510$, Eutech instruments, Netherlands) and $\mathrm{NaCl}$ following Mohr's method. Challenge test was performed in whey cheese "skuta" (shelf-life 8 days) inoculated with mixed culture of L. monocytogenes (two strains of cheese origin and L. monocytogenes ATCC 7644). The strains were grown in Brain Hearth Infusion Broth (bioMerieux, France) at $37^{\circ} \mathrm{C}$ for $24 \mathrm{~h}$. One $\mathrm{ml}$ of each culture was centrifuged at $10000 \mathrm{~g}$ for $10 \mathrm{~min}$, followed by supernatant removal and washing the cells with sterile saline water. Cells were diluted in $1 \mathrm{ml}$ of sterile saline water and serially diluted to determine the cell number, using PALCAM agar (Merck, Germany) incubated at $37^{\circ} \mathrm{C}$ for $24-48 \mathrm{~h}$.

Table 1. Sampling scheme and parameters monitored in cheese during shelf-life

\begin{tabular}{|c|c|c|c|c|c|}
\hline Cheese type & Cheese name & Shelf-life & $\begin{array}{c}\text { Time-point } \\
\text { sampling }\end{array}$ & $\begin{array}{c}\text { Microbiological } \\
\text { parameters }\end{array}$ & $\begin{array}{l}\text { Chemical } \\
\text { parameters }\end{array}$ \\
\hline Soft cheese & $\begin{array}{l}\text { Whey cheese } \\
\text { Skuta } \\
\text { Škripavac }\end{array}$ & 15 days & Day $6,9,12,15$ & $\begin{array}{c}\text { Salmonella, } \\
\text { L.monocytogenes, } \\
\text { E.coli, } \\
\text { S. aureus, } \\
\text { yeasts, molds, lactic } \\
\text { acid bacteria }\end{array}$ & \\
\hline $\begin{array}{l}\text { Semi-hard } \\
\text { cheese }\end{array}$ & Trappist & 9 months & Month $3,4,6,9$ & $\begin{array}{c}\text { Salmonella, } \\
\text { L.monocytogenes, } \\
\text { E.coli, } \\
\text { S. aureus, } \\
\text { Sulfite- reducing } \\
\text { clostridia, lactic acid } \\
\text { bacteria }\end{array}$ & $\begin{array}{c}\text { Water activity, } \\
\mathrm{pH}, \\
\mathrm{NaCl}\end{array}$ \\
\hline Hard cheese & $\begin{array}{l}\text { Hard cheese in } \\
\text { olive oil }\end{array}$ & 15 months & $\begin{array}{c}\text { Month } \\
3,4,6,11,12,15\end{array}$ & $\begin{array}{c}\text { Salmonella, } \\
\text { L.monocytogenes, } \\
\text { E.coli, } \\
\text { S. aureus, } \\
\text { Sulfite- reducing } \\
\text { clostridia, lactic acid } \\
\text { bacteria }\end{array}$ & \\
\hline
\end{tabular}

For microbiological analyses, $25 \mathrm{~g}$ of sample was diluted in $225 \mathrm{ml}$ of appropriate media (Buffered Peptone Water, Half-Fraser Broth or Peptone salt water) and homogenized for 2 min (Stomacher, Sedward, UK). Serial decimal dilutions were prepared and $0.1 \mathrm{ml}$ or $1 \mathrm{ml}$ of selected dilution were used for evaluation of lactic acid bacteria count (MRS, Merck, Darmstadt, Germany) at $30^{\circ} \mathrm{C}$ for 48 h, Staphylococcus aureus (Baird Parker agar, Merck, Germany) at $37^{\circ} \mathrm{C}$ for $48 \mathrm{~h}$, Escherichia coli (Rapid E. coli, Bio-Rad, France) $37 / 44^{\circ} \mathrm{C}$ for $24 \mathrm{~h}$, and sulfite-reducing clostridia (Iron Sulphyte Agar, bioMerieux, Marcy l'Etoile, France). Salmonella spp. was determined following a standard ISO 6579 method and Molecular Detection System (MDS, 3M, USA). L. monocytogenes presence and count was determined using ISO 11290-1 and 11290-2, respectively.

Water activity $\left(\mathrm{a}_{\mathrm{w}}\right)$ was determined by means of HygroPalm AW1 (Rotronic, Switzerland), 60
Appropriate dilutions were taken for cheese portion inoculation to obtain an inoculation level of 30-50 $\mathrm{cfu} / \mathrm{g}$. Cheese samples were inoculated in triplicate, vacuum-packed and stored at $4^{\circ} \mathrm{C}$ for 8 days. L. monocytogenes count, $\mathrm{pH}$ and water activity were determined at day 0 and at the end of shelf-life.

\section{RESULTS}

The results of the microbiological and chemical analyses of cheeses during the storage are summarized in Table 2. Foodborne pathogens Salmonella spp. and L. monocytogenes were absent in all cheese samples analyzed during the shelflife. Escherichia coli, L. monocytogenes, sulfitereducing clostridia and $S$. aureus were below the detection limits of the methods used at all sampling points. 
Microbiological quality of soft, semi-hard and hard cheeses during the shelf-life

L. monocytogenes counts were below $10 \mathrm{cfu} / \mathrm{g}$ in all cheese samples during storage. Population of lactic acid bacteria increased during the storage of soft cheeses, reaching 7-8 log cfu/g at the end of shelf-life. The $\mathrm{pH}$ values, water activity and $\mathrm{NaCl}$ content in soft cheeses were in the range of Listeriasupporting values. Semi-hard and hard cheeses were characterized by decrease of lactic acid bacteria counts during the storage and a slight $\mathrm{pH}$ increase. The $\mathrm{pH}$ values and $\mathrm{NaCl}$ content found in semihard and hard cheeses were not a limiting factor for Listeria growth. However, it is evident that water activity was below values that enables the growth of most foodborne pathogens.

Since soft cheeses showed to be supporting of Listeria growth according to their physico-chemical characteristics, the challenge test was performed with L. monocytogenes. Results of L. monocytogenes growth potential in whey cheese skuta are shown in Table 3, as well as $\mathrm{pH}$ and $\mathrm{a}_{\mathrm{w}}$ values (Table 4). Despite high water activity and optimal $\mathrm{pH}, L$. monocytogenes inoculated in low numbers (30-50 $\mathrm{cfu} / \mathrm{g})$ didn't reach a critical limit of $100 \mathrm{cfu} / \mathrm{g}$ in cheese stored at $4{ }^{\circ} \mathrm{C}$ for 8 days.

\section{DISCUSSION}

Microbiological quality and interpretation of microbiological findings of different kind of cheeses depends on the sampling points during the production or retail phase. In present study, the

Table 2. Results of microbiological and physico-chemical analyses of cheeses during the shelf-life

\begin{tabular}{|c|c|c|c|c|c|c|}
\hline \multirow{2}{*}{ Cheese type } & \multirow{2}{*}{ Cheese name } & \multirow{2}{*}{$\begin{array}{l}\text { Microbiological } \\
\text { parameter and } \\
\text { sampling day }\end{array}$} & \multirow{2}{*}{$\begin{array}{l}\text { Microbial } \\
\text { counts } \\
\left(\log _{10} \mathrm{cfu} / \mathrm{g}\right)\end{array}$} & \multicolumn{3}{|c|}{$\begin{array}{c}\text { Results of physico-chemical } \\
\text { analyses }\end{array}$} \\
\hline & & & & pH & $a_{w}$ & $\mathrm{NaCl}(\%)$ \\
\hline \multirow{19}{*}{ Soft cheese } & \multirow{8}{*}{$\begin{array}{c}\text { Whey cheese } \\
\text { Skuta }\end{array}$} & Lactic acid bacteria & & & & \\
\hline & & Day 5 & $4.20 \pm 0.07$ & $6.21 \pm 0.02$ & $0.945 \pm 0.01$ & $0.12 \pm 0.02$ \\
\hline & & Day 7 & $4.60 \pm 0.05$ & $6.53 \pm 0.01$ & $0.960 \pm 0.01$ & $0.23 \pm 0.03$ \\
\hline & & Day 8 & $6.80 \pm 0.02$ & $5.80 \pm 0.02$ & $0.990 \pm 0.01$ & $0.29 \pm 0.04$ \\
\hline & & Yeasts & & & & \\
\hline & & Day 5 & $2.47 \pm 0.01$ & & & \\
\hline & & Day 7 & $2.77 \pm 0.11$ & & & \\
\hline & & Day 8 & $2.95 \pm 0.12$ & & & \\
\hline & \multirow{11}{*}{ Škripavac } & Lactic acid bacteria & & & & \\
\hline & & Day 6 & $6.62 \pm 0.15$ & $6.28 \pm 0.02$ & $0.950 \pm 0.02$ & $1.10 \pm 0.02$ \\
\hline & & Day 9 & $6.50 \pm 0.07$ & $6.40 \pm 0.03$ & $0.960 \pm 0.01$ & $1.10 \pm 0.02$ \\
\hline & & Day 12 & $7.25 \pm 0.12$ & $6.55 \pm 0.03$ & $0.978 \pm 0.02$ & $1.20 \pm 0.01$ \\
\hline & & Day 15 & $7.82 \pm 0.14$ & $6.20 \pm 0.01$ & $0.990 \pm 0.02$ & $1.22 \pm 0.02$ \\
\hline & & & & & & \\
\hline & & Yeasts & & & & \\
\hline & & Day 6 & $2.30 \pm 0.11$ & & & \\
\hline & & Day 9 & $2.54 \pm 0.06$ & & & \\
\hline & & Day 12 & $2.58 \pm 0.07$ & & & \\
\hline & & Day 15 & $2.77 \pm 0.10$ & & & \\
\hline \multirow{4}{*}{$\begin{array}{l}\text { Semi-hard } \\
\text { cheese }\end{array}$} & \multirow{4}{*}{ Trappist } & $\begin{array}{l}\text { Lactic acid bacteria } \\
\text { Day } 90\end{array}$ & $6.20 \pm 0.12$ & $5.40 \pm 0.04$ & $0.910 \pm 0.01$ & $1.51 \pm 0.02$ \\
\hline & & Day 120 & $5.04 \pm 0.10$ & $5.48 \pm 0.02$ & $0.900 \pm 0.04$ & $1.68 \pm 0.03$ \\
\hline & & Day 180 & $4.80 \pm 0.08$ & $5.80 \pm 0.04$ & $0.866 \pm 0.03$ & $2.12 \pm 0.06$ \\
\hline & & Day 270 & $4.62 \pm 0.10$ & $5.96 \pm 0.02$ & $0.806 \pm 0.02$ & $2.85 \pm 0.03$ \\
\hline \multirow{12}{*}{ Hard cheese } & \multirow{7}{*}{ Livanjski } & Lactic acid bacteria & & & & \\
\hline & & Day 90 & $7.20 \pm 0.15$ & $5.52 \pm 0.03$ & $0.900 \pm 0.02$ & $1.85 \pm 0.02$ \\
\hline & & Day 120 & $5.83 \pm 0.10$ & $5.60 \pm 0.02$ & $0.907 \pm 0.05$ & $2.20 \pm 0.02$ \\
\hline & & Day 180 & $4.60 \pm 0.12$ & $5.72 \pm 0.05$ & $0.880 \pm 0.03$ & $2.28 \pm 0.04$ \\
\hline & & Day 330 & $3.40 \pm 0.12$ & $5.80 \pm 0.02$ & $0.795 \pm 0.03$ & $3.30 \pm 0.01$ \\
\hline & & Day 360 & $2.20 \pm 0.05$ & $5.92 \pm 0.02$ & $0.791 \pm 0.06$ & $3.35 \pm 0.02$ \\
\hline & & Day 450 & $2.00 \pm 0.02$ & $5.97 \pm 0.02$ & $0.650 \pm 0.04$ & $3.62 \pm 0.03$ \\
\hline & \multirow{5}{*}{$\begin{array}{l}\text { Hard cheese in } \\
\text { olive oil }\end{array}$} & Lactic acid bacteria & & & & \\
\hline & & Day 90 & $6.80 \pm 0.11$ & $5.72 \pm 0.02$ & $0.890 \pm 0.02$ & $1.74 \pm 0.02$ \\
\hline & & Day 150 & $6.78 \pm 0.14$ & $5.80 \pm 0.04$ & $0.870 \pm 0.03$ & $1.75 \pm 0.02$ \\
\hline & & Day 240 & $6.75 \pm 0.05$ & $5.84 \pm 0.03$ & $0.842 \pm 0.04$ & $1.80 \pm 0.04$ \\
\hline & & Day 270 & $6.42 \pm 0.04$ & $5.90 \pm 0.03$ & $0.760 \pm 0.04$ & $1.92 \pm 0.03$ \\
\hline
\end{tabular}


Table 3. Growth potential of Listeria monocytogenes in whey cheese skuta

\begin{tabular}{|c|c|c|c|c|}
\hline Batch & Sample & $\begin{array}{c}\text { L. monocytogenes } \\
\text { number }\left(\log _{10} \mathrm{cfu} / \mathrm{g}\right) \\
\text { Day } 0\end{array}$ & $\begin{array}{c}\text { L. monocytogenes } \\
\text { number }\left(\log _{10} \mathrm{cfu} / \mathrm{g}\right) \\
\text { Day } 8\end{array}$ & $\begin{array}{l}\text { Growth potential } \\
\quad\left(\log _{10} \mathrm{cfu} / \mathrm{g}\right)\end{array}$ \\
\hline \multirow{3}{*}{ I } & $1 \mathrm{a}$ & 1 & 1.84 & \multirow{3}{*}{0.24} \\
\hline & $1 b$ & 1.60 & 1.90 & \\
\hline & $1 \mathrm{c}$ & 1.69 & 1.69 & \\
\hline \multirow{3}{*}{ II } & $2 \mathrm{a}$ & 1.47 & 1.90 & \multirow{3}{*}{0.43} \\
\hline & $2 b$ & 1.30 & 1.95 & \\
\hline & $2 \mathrm{c}$ & 1.69 & 1.95 & \\
\hline \multirow{3}{*}{ III } & $3 a$ & 1.30 & 1.69 & \multirow{3}{*}{0.09} \\
\hline & $3 b$ & 1.60 & 1.30 & \\
\hline & $3 c$ & 1.69 & 1.90 & \\
\hline
\end{tabular}

Table 4. $\mathrm{pH}$ and aw in whey cheese skuta during challenge test

\begin{tabular}{cccccc}
\hline \multirow{2}{*}{ Batch } & Sample & \multicolumn{2}{c}{ Day 0 } & \multicolumn{2}{c}{ Day 8 } \\
\cline { 3 - 6 } & 1a & $\mathbf{p H}$ & $\mathbf{a}_{\mathbf{w}}$ & $\mathbf{p H}$ & $\mathbf{a}_{\mathbf{w}}$ \\
\hline \multirow{2}{*}{$\mathbf{I}$} & $1 \mathrm{~b}$ & 6.22 & 0.952 & 5.80 & 0.992 \\
& $1 \mathrm{c}$ & 6.30 & 0.950 & 5.48 & 0.996 \\
& $2 \mathrm{a}$ & 6.06 & 0.955 & 5.62 & 0.998 \\
\hline \multirow{2}{*}{ II } & $2 \mathrm{~b}$ & 6.42 & 0.960 & 5.45 & 0.993 \\
& $2 \mathrm{c}$ & 6.23 & 0.958 & 5.50 & 0.997 \\
\hline \multirow{2}{*}{ III } & $3 \mathrm{a}$ & 6.30 & 0.950 & 5.62 & 0.998 \\
& $3 \mathrm{~b}$ & 6.17 & 0.952 & 5.50 & 0.998 \\
& $3 \mathrm{c}$ & 6.15 & 0.980 & 5.46 & 0.997 \\
\hline
\end{tabular}

phase of post-processing was monitored in order to evaluate compliance with microbiological criteria, with particular reference to L. monocytogenes counts. In relation to overall microbiological quality, results showed that soft, semi-hard and hard cheeses were microbiologically stable during their defined shelf-life. Microbiological stability of semi-hard and hard cheeses relies on several hurdles including starter cultures competitiveness, increased salt content and, most importantly, low water activity $(2,9)$. Physico-chemical values and their changes during the storage of semi-hard and hard cheeses in our study are in line with previous reports $(11,13,15)$. L. monocytogenes was not present in viable counts, however it should be stressed that secondary contamination is possible during the cutting of the cheese into quarters or halves, followed by packaging. Prevention of contamination with Listeria at this point should be based on Good Hygienic Practice and verification of sanitation programs.

Soft cheeses in general are of limited durability, because of high moisture content and high $\mathrm{pH}$ which support the proliferation of some spoilage microorganism like Enterobacter spp. 62 or Pseudomonas spp. under cold storage (8). Whey cheese (skuta) used in our study showed physicochemical characteristics comparable with other similar products from the Mediterranean area $(1,10,16)$. During the storage of whey cheese skuta the $\mathrm{pH}$ decreased and lactic acid bacteria count increased which is in accordance with other studies $(10,16)$. Lactic acid bacteria are known to be beneficial and functional microbes in many different dairy products (20), however their outgrowth in this kind of products (whey cheese) could contribute to spoilage (8). Soft cheeses are ready-to-eat products that support the growth of L. monocytogenes based on their physic-chemical characteristics $(14,18)$, which is also presented by the results in current survey ( $\mathrm{pH}$ values 5.8-6.5, water activity 0.99-0.94 and $\mathrm{NaCl}$ content $0.3-1.2 \%$ ). Challenge test showed that $L$. monocytogenes growth potential in whey cheese was $0.43 \log _{10} \mathrm{cfu} / \mathrm{g}$ during 8 days at $4^{\circ} \mathrm{C}$, meaning that the proposed shelf-life is acceptable for products stored under defined conditions. Many studies from last decades emphasized that $L$. monocytogenes represents a serious public-health problem due to high prevalence in soft cheeses $(7,17,19)$. Recent studies are more focused on 
bacterial kinetics in cheeses made from pasteurized milk during their shelf-life at different storage conditions, and related application of bio-protective strategies (3).

\section{CONCLUSION}

Compliance with microbiological criteria at the end of cheese production (final product) doesn't guarantee that microbiological hazards are excluded. Listeria monocytogenes is a ubiquitous bacteria and secondary contamination of products is possible under poor hygienic conditions. Despite the fact that the growth of the pathogen is limited in semi-hard and hard cheeses by low water activity, the secondary (surface) contamination could result in hazardous products. The significance of following strict hygienic procedures is evident even more in soft cheese production, since they support the growth of L. monocytogenes.

\section{REFERENCES}

1. Antunac, N., Hudik, S., Mikulec, N., Maletić, M., Horvat, I., Radeljević, B., Havranek, J. (2011). Proizvodnja i kemijski sastav Istarske i Paške skute. Mljekarstvo 61, 326-335. (in Croatian)

2. Bishop, J.R., Smukowski, M. (2006). Storage temperatures necessary to maintain cheese safety. Food Protect. Trends 26, 714-724.

3. Coelho, M.C., Silva, C.C.G., Ribeiro, S.C., Dapkevicius, M.L.N.E., Rosa, H.J.D. (2014). Control of Listeria monocytogenes in fresh cheese using protective lactic acid bacteria. Int. J. Food Microbiol. 191, 53-59.

http://dx.doi.org/10.1016/j.ijfoodmicro.2014.08.029 PMid:25222327

4. Commision regulation (EC) No 2073/2005 on microbiological criteria for foods. Official Journal of the European Union L338/1-338/26.

5. Donelly, C.W. (2004). Growth and survival of microbial pathogens in cheese. In: Fox, P.F., McSweeney, P.L.H., Cogan, T.M., Guinee, T. P. (Eds.), Cheese - Chemistry, Physics and Microbiology, Third Edition - Vol. 1: general aspects. (pp 541-559), London: Elsevier Ltd. http://dx.doi.org/10.1016/s1874-558x(04)80081-2

6. EFSA (2013). Analysis of the baseline survey on the prevalence of Listeria monocytogenes in certain ready-to-eat foods in the EU, 2010-2011 Part A: Listeria monocytogenes prevalence estimates. EFSA Jounal 11, 3241.

7. Kozačinski, L., Hadžiosmanović, M. (2001). The occurrence of Listeria monocytogenes in home-made dairy products. Tierartz Umsch. 56, 590-594.
8. Ledenbach, L.H., Marshall, L.T. (2009). Microbiological spoilage of dairy products. In: Sperber, W.H., Doyle, M.P. (Eds.), Compendium of the microbiological spoilage of foods and beverages (pp 41-67), Springer Science.

ttp://dx.doi.org/10.1007/978-1-4419-0826-1_2

9. Leong, W.M., Geier, R., Engstrom, S., Ingham, S., Ingham, B., Smukowski, M. (2014). Growth of Listeria monocytogenes, Salmonella spp., Escherichia coli O157:H7 and Staphylococcus aureus on cheese during extended storage at $25^{\circ} \mathrm{C}$. J. Food Protect. 77 , 1275-1288.

http://dx.doi.org/10.4315/0362-028X.JFP-14-047

PMid:25198588

10. Litopoulou-Tzanetaki, E., Tzanetakis, N. (2011). Microbiological characteristics of Greek traditional cheese. Small Rum Res. 101, 17-32.

http://dx.doi.org/10.1016/j.smallrumres.2011.09.022

11. Marijan, A., Džaja, P., Bogdanović, T., Škoko, I., Cvetnić, Ž., Dobranić, V., Zdolec, N., Šatrović, E., Sverin, K. (2014). Influence of ripening time on the amount of certain biogenic amines in rind and core of cow milk Livno cheese. Mljekarstvo 64, 159-169. http://dx.doi.org/10.15567/mljekarstvo.2014.0303

12. Markov, K., Frece, J., Čvek, D., Delaš, F. (2009). Listeria monocytogenes and other contaminants in fresh cheese and cream from Zagreb city area domestic production. Mljekarstvo 59, 225-231.

13. Matić, A., Kalit, S., Salajpal, K., Ivanković, S., Sarić, Z. (2014). Consumers' preferences and composition of Livanjski cheese in relation to its sensory characteristics. Mljekarstvo 64, 170-177. http://dx.doi.org/10.15567/mljekarstvo.2014.0304

14. Melo, J., Andrew, P.W., Faleiro, M.L. (2015). Listeria monocytogenes in cheese and the dairy environment remains a food safety challenge: The role of stress responses. Food Res. Int. 67, 75-90.

http://dx.doi.org/10.1016/j.foodres.2014.10.031

15. Merćep, A., Kirin, S., Zdolec, N., Cvrtila Fleck, Ž., Filipović, I., Njari, B., Mitak, M., Kozačinski, L. (2010). Quality of Trappist cheese from Croatian dairy plant. Mljekarstvo 60, 288-298.

16. Papaioannou, G., Chouliara, I., Karatapanis, A.E., Kontominas, M.G., Savvaidis, I.N. (2007). Shelf-life of a Greek whey cheese under modified atmosphere packaging. Int. Dairy J. 17, 358-364. http://dx.doi.org/10.1016/j.idairyj.2006.04.001

17. Pintado, C.M.B.S., Oliveira, A., Pampulha, M.E., Ferreira, M.A.S.S. (2005). Prevalence and characterization of Listeria monocytogenes isolated from soft cheese. Food Microbiol. 22, 79-85. http://dx.doi.org/10.1016/j.fm.2004.04.004 
18. Rosshaug, P.S., Detmer, A., Ingmer, H., Larsen, M.H. (2012). Modeling the growth of Listeria monocytogenes in soft Blue-White cheeses. Appl. Environ. Microbiol. 78, 8508-8514.

http://dx.doi.org/10.1128/AEM.01865-12

PMid:22983971 PMCid:PMC3502931

19. Rudolf, M., Scherer, S. (2001). High incidence of Listeria monocytogenes in European red smear cheese. Int. J. Food Microbiol. 63, 91-98.

http://dx.doi.org/10.1016/S0168-1605(00)00413-X
20. Zdolec, N., Lazić, S., Kozačinski, L., Hadžiosmanović, M., Filipović, I. (2007). The inhibitory activity of lactic acid bacteria isolated from fresh cow cheese. Mljekarstvo 57, 5-13. 